\title{
Morphology and histology of dorsal spines of the xenacanthid shark Orthacanthus platypternus from the Lower Permian of Texas, USA: palaeobiological and palaeoenvironmental implications
}

\author{
Kimberly G. Beck, Rodrigo Soler-Gijón, Jesse R. Carlucci, and Ray E. Willis \\ Acta Palaeontologica Polonica 61 (1), 2016: 97-117 doi:http://dx.doi.org/10.4202/app.00126.2014
}

Detailed studies on Carboniferous species of the xenacanth Orthacanthus have shown that the xenacanth dorsal fin spine can be used for skeletochronological analyses and provides valuable information about development, growth and environmental life conditions of those extinct sharks. We report here for the first time the histology and skeletochronology of Permian specimens, dorsal spines of Orthacanthus platypternus from the Craddock Bone Bed (lower Clear Fork Formation; Early Permian, Leonardian age) of northern Baylor County (north-central Texas, USA). Twelve dorsal spines of $O$. platypternus preserve a highly vascularized wall mainly composed of centrifugally growing dentine in a succession of dentine layers, probably deposited with an annual periodicity. As expected, spines of individuals with 1-2 dentine layers, presumably juveniles, present the smallest sizes. However, spines of individuals showing at least 3-4 dentine layers and interpreted to be subadults/young adults, are distributed in two spine-size clusters corresponding to females (probably the largest spines) and males, in agreement with the hypothesis of sexual size dimorphism proposed in a previous biometric analysis. Our comparative study of $O$. platypternus and the Stephanian species $O$. meridionalis further suggests that spine denticulation can be useful for distinguishing between species of Orthacanthus and sexually dimorphic forms (juvenile to adults) in each species. Total body length estimations of $O$. platypternus from the Craddock Bone Bed point to relatively large juveniles and small subadults/young adults (less than $2 \mathrm{~m}$ in total length), living as opportunistic predators in the pond-channel coastal plain environments represented by the bone bed deposits. The com-parative analyses of the ontogenetic stages of the recorded specimens of $O$. platypternus and their distribution along different facies and localities indicate that this species was euryhaline, diadromous with a catadromous life-cycle which was strongly regulated by the semi-arid, seasonally dry tropical climate affecting western Pangaea during the Early Permian

Key words: Chondrichthyes, Xenacanthiformes, Orthacanthus, dorsal spine, diadromy, histology, Permian, Texas.

Kimberly G. Beck [kimberly.beck@mwsu.edu] and Ray E. Willis [raymond.willis@mwsu.edu ], Department of Biology, Midwestern State University, 3410 Taft Boulevard, Wichita Falls, TX 76308, USA. Rodrigo Soler-Gijón [rodrigo.solergijon@gmail.com 
], Museum für Naturkunde-Leibniz Institute for Evolution and Biodiversity Science, Invalidenstrasse 43, 10115, Berlin, Germany. Jesse R. Carlucci [jesse.carlucci@mwsu.edu], Department of Geology, Midwestern State University, 3410 Taft Boulevard, Wichita Falls, TX 76308, USA.

This is an open-access article distributed under the terms of the Creative Commons Attribution License (for details please see creativecommons.org), which permits unrestricted use, distribution, and reproduction in any medium, provided the original author and source are credited.

FoF Full text $(4,275.6 \mathrm{kB})$ 